\title{
THE DEVELOPMENT OF WEB LEARNING BASED ON PROJECT IN THE LEARNING MEDIA COURSE AT IAIN KENDARI
}

\author{
Ambar Sri Lestari \\ Institut Agama Islam Negeri (IAIN) Kendari, Southeast Sulawesi \\ Jl. Sultan Qaimuddin No.17, Baruga, Kota Kendari, Sulawesi Tenggara, Indonesia \\ Email: ambarlstr@gmail.com \\ Received: 07, 2018. Accepted: 07, 2019. Published: 07, 2019.
}

\begin{abstract}
This study aims to explain the development of multimedia through project-based learning. The method used in this study is Research \& Development $(\mathrm{R} \& \mathrm{D})$ depleted to analyze the learning products results. The object of this research is 30 students of PAI (Pendidikan Agama Islam/Islamic Education) study program in learning media. The data were collected using observation on students' presentation before using multimedia, doing an interview to identify students' argumentation in delivering the material before and after using multimedia presentation and product test through the individual test, small group test and field study test. Multimedia development procedures were using the ADDIE model, namely: Analysis, Design, Development, Implementation and Evaluation. The results showed that the teaching of multimedia based on Project Based Learning could improve the student learning mastery as for the whole process is interactive and interesting, giving the students the opportunity to be creative and innovative in making multimedia teaching materials. Multimedia teaching materials were stored on youtube and can be viewed on web e-learning http: //www.elearning-ambarsrilestari.web. id. In addition, paper materials were uploaded on blogs, while module teaching materials were uploaded on Slide share stored on e-portfolio on www.ambarsrilestari.web.id.
\end{abstract}

Keywords: Analysis, Multimedia, Web based Learning, PAI Study Program Students

\begin{abstract}
ABSTRAK
Penelitian ini bertujuan untuk. menjelaskan pengembangan multimedia melalui pembelajaran berbasis proyek. Penelitian ini menggunakan metode penelitian pengembangan $(\mathrm{R} \& \mathrm{D})$ yang digunakan untuk menguji hasil produk pembelajaran. Obyek penelitian adalah mahasiswa program studi P AI (Pendidikan Agama Islam) sebanyak 30 siswa. Pengumpulan data dilakukan dengan menggunakan observasi pada pembuatan presentasi mahasiswa sebelum menggunakan multimedia, wawancara untuk mengetahui argumentasi mahasiswa dalam menyampaikan materi sebelum dan sesudah menggunakan presentasi multimedia dan uji produk melalui tes individu, tes kelompok kecil dan tes lapangan. Prosedur pengembangan multimedia menggunakan model ADDIE yaitu: Analisis, Desain, Pengembangan, Implementasi dan Evaluasi. Hasil penelitian menunjukean bahwa pengajaran multimedia berbasis Project Based Learning dapat meningkatkan penguasaan pembelajaran mahasiswa karena bersifat interaktif dan menarik, memberikan kesempatan kepada mahasiswa untuk melakukan kreatifitas dan inovasi dalam membuat bahan ajar multimedia. Baban ajar multimedia disimpan pada youtube dan dapat dilihat pada web e-learning bttp: / / wnw.elearning-ambarsrilestari.web. id. Selain itu, bahan ajar paper diupload pada blog dan bahan ajar modul diupload pada slideshare yang disimpan pada eportofolio pada web wnw. ambarsrilestari.web.id.
\end{abstract}

Kata Kunci: Analisis, Multimedia, Pembelajaran Berbasis Proyek, Mahasiswa Program Studi PAI

\section{INTRODUCTION}

Education has always paid attention to learning media for teaching and learning. Learning media is a means of delivering messages or content in learning by using various media to explain the material so that it can be better understood by students. It can be done using various methods and one of them is using project-based learning methods. This method allows teachers to give 
students assignment to make material presentations in the form of presentations that combine multimedia elements.

This paper will discuss project-based multimedia (PBM) teaching as a medium in learning. PBM has now been carried out in the field of teaching to support the learning process in class and provide different learning experiences to students. Patmanthara (2016) explains that learning which is based on the project can improve student learning outcomes in several aspects namely knowledge, attitudes, and skills. To carry out this method, learning media is required since it serves as a tool that functions to convey a message.

In an educational enterprise, media is a means of channeling messages or information to be conveyed by the teacher to the target or recipient of the message or students (Mahnun, 2012). The media is used to deliver the presentation of material the process of teaching and learning so that students can understand the concepts explained. They may combine multimedia elements they received. To deliver material using multimedia is more interesting and easier for students to understand. For example, an assignment can be given to students and they are required to be able to make presentation of material in the form of presentations. Media has been included in educational components that are very important in learning. It can be seen to function as a teaching aid that can influence students' motivation, conditions and learning environment.

To achieve learning objectives, teachers may select several learning models. One of them is project-based learning (PBL) which uses problems as the first step in gathering and integrating new knowledge based on students' experience (Idkhan, 2017). In applying PBL, the media is required to facilitate students' learning. Teachers may deliver their material in the form of presentations so that students can understand the concepts explained. Combining multimedia elements makes delivery of material more interesting and easier for students to understand. In addition, an assignment can be given to students and it requires them to be able to make presentation of material in the form of presentations.

PBL has been implemented in higher education context. In Islamic higher education, several studies have reported the implementation of PBL that facilitates comprehensive learning. Baedowi \& Aksin (2017) said that a comprehensive learning that includes theoretical and practical material in the educational field is needed through project-based learning. To carry out PBL in Islamic education department, real action in the form of learning projects can be done by students and it can be reflected in their daily life. Prospective student teachers are required to be able to follow technological developments so that the presentation of material in the class can be more innovative and can foster interest in learning in students, so it is expected to improve learning outcomes in the subjects taught. The material in the field of education, both religion and general, is very diverse and requires innovation in its delivery so that it is also expected to create creativity in students.

In Islamic higher education institutions, teaching and learning carried out in class needs to be improved. Some institutions are focused on conventional methods such as lectures and discussions and have not implemented innovative methods to achieve educational objectives. Fannani (2018)) in his research found that the learning of Kemubammadiyahan Education was less innovative and students' learning interest was low. It required the development of teaching materials using interactive multimedia with a project-based learning model to improve learners' motivation.

There is a need to improve the existing learning condition in Islamic higher education. Fatmawati (2011) found that the poor creativity development is due to learning in higher education that emphasized memorization. This makes it difficult for students to find solutions in solving problem in contrast, convergent thinking skills should be promoted to students. This skill nurtures the ability to find one answer correctly to the problem given based on available 
information. In addition, fun learning must be delivered to students. By integrating information technology into teaching material, students and teachers must be able to adapt to evolving technological changes. It activates learning methods to solve problems and improve students' skills, so that learning objectives can be achieved. For example, to measure students' creativity, they can express in the form of assignments of work such as making products in the form of presentations that combine multimedia elements so they will be more motivated in learning.

Learning should be organized well to achieve educational objectives. Government Regulation No. 65 of 2013 states that the learning process both at school and university must be well organized in an interactive, inspiring, fun, challenging, motivating learner to actively participate, and providing enough space to develop initiative, creativity and independence according to the talents, interests, and physical and psychological development of learners. However, not all lecturers or teachers can apply the lessons according to this government regulation.

One of the learning models that can trigger student creativity is a project-based learning (PBL) model. PBL is one alternative learning that is not only for assessing cognitive aspects but also for student work, where students are actively encouraged to be more independent in learning. As explained Naimah (2015) states that project-based learning contributes to improving student learning outcomes. According to Sanjaya (2006): the Project Based learning model is a learning model that provides an opportunity for teachers to manage to learn in class involving project work. Project work is a form of swork that contains complex tasks based on questions and problems that are very challenging and guides students to design, solve problems, make decisions, conduct investigative activities, and provide opportunities for students to work independently.

PBL has several stages to implement. Its stages include discovering ideas such as the presentation of material to be made, designing the presentation of the material made, using a tutorial or by using videos, making work plans, monitoring progress of work, assessing work results and finally evaluating from previous experience. According to Rais (2010): the steps of the PBL model are as follows: starting with the big question, designing a plan for the project, creating a schedule, monitoring the students and the progress of the project, assessing the outcome and evaluating the experience. In the same vein, Jalaluddin (2016) explains that the steps of project-based learning, including starting with the essentials questions, design a plant for the project, create schedules, monitor the students and the progress of the projects, assess the outcome, and evaluate the experience.

The internet is also a learning experience for students in the learning process. By using web-based learning, it is expected to provide motivation to learn and create technology-based learning innovations. The internet is also one form of media that can be used in learning because the internet is a learning resource that becomes a supporting medium in teaching where the internet is connected to sources obtained virtually, as stated by Makky \& Chatib (2016) explained that internet integration as a medium for learning has a major impact on student learning motivation, this is due to the fact that changes in the higher learning model have entered the digital era including increasingly fierce competition.

Internet offers benefits for student in learning. It boosts creativity and innovation on the parts of students. It will have an impact on high learning motivation and eventually it strengthens to achieve expected learning outcomes. Increasingly complex problems faced by the world of work demanding graduate to possess skills, to perform transferable skills. It encourages students to nurture four pillars of lifelong learning, namely learning to know, learning to do, learning to be, learning to live together (Kurdish, 2009).

Based on the observation, in State Islamic Institute / IAIN Kendari, the learning process in the classroom is still monotonous, unpleasant and it is not challenging for students to develop 
their creativity. Teaching and learning at IAIN Kendari, in general, is still done by using lecture methods and discussions that are less exploring for the ability of students in assignments. When delivering material, teachers should combine multimedia elements so that the material to be presented can be more interesting and uphold students' motivation. In addition, the improper application of learning models and the suitability of the material with the syllabus is also a problem for the students. As a result, students become saturated for learning, low motivation, and interest in learning as well as the learning achievement (Philip, Jackson, \& Wando, 2011).

Several problems in PAI Learning have been reported by researchers. It is still monotonous or less interesting in explaining the theory that is also done with practice. It is expected that the delivery of PAI material should be more interesting and the form of material presentation must be supported by integrating technology. Adding multimedia elements to make material or concept in question easier to understand and interesting for students. A study on integration of technology on material presentation has been reported in a research. Wulandari (2016) conducted study at the Muhammadiyah University in education faculty and reported good result on learning process skills using PBL. This happened because students were directed in various process skills activities such as observing, formulating problems, asking questions, planning experiments, using media, and analyzing. PBL is a systematic learning method where students are involved in learning knowledge, skills through inquiry processes through well-designed tasks and products.

Previous studies on PBL implementation using multimedia at Islamic state universities have not been reported extensively. This study tries to fill the gap. Based on the problem put forward previously in IAIN Kediri, this study sought to explore PBL as a learning model to deliver the material in teaching and learning. The learning model is expected to create student creativity in their learning process. This learning model uses a project or activity as a medium. Students can explore, assess, interpret, synthesize, and information to produce various forms of learning outcomes.

\section{METHOD}

The purpose of this study is to investigate PBL with the presentation of a combination of multimedia elements such as text, sound, images, animation, and video to support the presentation of the material delivered. This study discusses the integration of multimedia within the scope of e-learning. To answer the research question, this study adopts the definition of multimedia proposed by Chapman \& Chapman (2004). Multimedia in this context is defined as a message which is sent and it is divided into two types, namely delivery online and offline. In general, the data were collected using observation, interview and documentation

This study deployed a research and development design ( $\mathrm{R}$ and $\mathrm{D}$ ) proposed by Dick, Carey, \& Carey (2009) conceptual model. This model includes a procedural model in which the steps to be followed consisting of five steps: (1) Analysis, (2) Design, (3) Development, (4) Implementation and (5) Evaluation. In a more detailed description, stages of study are as follows: 1) the first stage, analysis. In this stage, the student presentation before they applied multimedia is investigated; 2) the second stage, design. In this phase, the explanation of the content of the material was combined with the multimedia elements to achieve students' understanding; 3) the third stage is product development. To accomplish this stage, previous stages of multimedia design was linked to web e-learning; 4) the fourth stage is project-based multimedia (PBM) implementation. This was done using additional applications such as Camtasia; 5) and the fifth stage is evaluation. This study administered several tests namely individual, small group, and field test. The test was constructed using as many as 17 validated indicator items tested. Students belonging to PAI B and C classes academic year 2016-2017 participated in the test. They were 30 students. Multimedia learning material products that have 
been made are then tested through several stages namely on individual tests with 6 students; small group test with 9 students and field tests with 15 students

\section{RESULTS AND DISCUSSION}

This study has collected several data. First, assignments for students to make presentations by combining multimedia elements in the presentation of material. Second, administration of test on several stages namely an individual, small group, and field test. This test aimed to see the effectiveness of the use of multimedia presentations as assignments in PBL. The test measured the responses of students and the percentage of the results of the assignment of making presentations with multimedia in improving their learning outcomes and learning motivation learning.

In developing the product of multimedia teaching and learning, there are several stages to accomplish. First, conducting analysis. This study observed the shortcomings in the conventional learning process without any technological learning innovations. The disadvantages of this conventional learning process is that it emphasized teacher role featuring lectures and discussion methods that were already common. These methods did not explore much the abilities of students when they were required to deliver material in groups. Students had no variety of teaching and learning activities and they found it boring and not interesting. Based on this analysis, there is a need to propose an effort to overcome this problem. To make learning interesting and lessen students' boredome, a touch of technology is needed.

Second step in this research and development product is design. Multimedia presentations that integrate sound, image, animation and even video elements into the material presentation were designed and created. In this stage, students were assigned to make presentations for the learning material by combining multimedia elements. Multimedia elements were used so that the material they delivered will be more interesting and could increase their learning motivation. This assignment challenged them to be more creative and innovative in designing and creating their product.

The third step is presentation project. In this step, students developed and used additional applications such as Camtasia to their product. It featured videos and this made their product more interesting so they were more focused on listening to the material presented. This presentation was an assignment project that must be accomplished by students. They designed and created material by combining multimedia elements. This step required their creativity. It was expected that their product could increase their understanding and learning motivation.

The fourth stage is implementation. This step refers to the activity where students presented their multimedia product. In this step students showcased their assignments to make presentations by combining multimedia elements in the presentation of material so that it can be more interesting and understandable.

This study discusses PBL as an assignment for student to create multimedia presentations. This PBL required students to combine multimedia elements such as text, sound, images, animation, and video to convey material more interestingly and understandably. After they completed the product, their multimedia projects were uploaded and stored on youtube using platform e-learning web www.elearning-ambarsrilestari.web.id. Storing their product online has several benefits. Students could repeat learning not only in the classroom (face to face) but also outside the classroom. Their learning could be performed anywhere and anytime. However, this learning process was still mostly done in the classroom to ensure that discussions session between peer tutors and teachers existed.

Fifth step is evaluation by looking at whether there were still shortcomings in making a presentation. Those multimedia products were tested through three stages of the test. There are several things to take into consideration when assessing the multimedia product in this 
evaluation step. The test assessed whether it has included multimedia elements into the delivery of material or it is still limited to simple presentations without any multimedia elements. The individual tests were taken by 6 students from the tested class. Next test was done in small group. There were 9 students from the tested class. The last is the field test which was taken by 15 students from the tested class. Tests were conducted to find out the multimedia-based learning products. Those products were expected to make learning better and more interesting for student compared to the delivery of learning in the conventional method without the use of multimedia.

There are several criteria to validate the multimedia product made by the students. Validated multimedia indicators were combined with web e-learning used in this study. Multimedia validation is important to see whether the material presented has combined multimedia elements or not. Their product should include the following elements: 1) audio/sound, 2) text, 3) photos/images, 4) animations, 5) videos, 6) material content, 7) background of teaching media with material, 8) use of hypertext, 9) graphics, 10) e-learning web access speed, 11) e-learning web view, 12) relationship between one material with other material, 13) color combination on the web learning, 14) consistency of instructions for using e-learning web, 15) ease of opening multimedia teaching materials on youtube on e-learning, 16) integration of paper assignment of papers on blog, 17) integration of module assignment on Slideshare. Those elements served as the criteria to assess the students' multimedia product.

Table 1. Individual Test Results, Smh all Group and Field Test

\begin{tabular}{|c|c|c|c|}
\hline No & Criteria & Empirical Score Result x 100\% & Description \\
\hline 1 & $\begin{array}{l}\text { Individual } \\
\text { Test }\end{array}$ & $\begin{array}{l}82 \% \text { was obtained from the sum of } \\
\text { each criterion score (see table } 2 \text { ) }\end{array}$ & $\begin{array}{l}\text { Meets multimedia elements including } \\
\text { sound, image, text, animation obtained by } \\
82 \% \text { through the individual test with a } \\
\text { sample of } 6 \text { students }\end{array}$ \\
\hline 2 & $\begin{array}{c}\text { Small } \\
\text { Group } \\
\text { Test }\end{array}$ & $\begin{array}{l}84 \% \text { was obtained from the sum of } \\
\text { each criterion score (see table } 3 \text { ) }\end{array}$ & $\begin{array}{l}\text { Meets multimedia elements including } \\
\text { sound, image, text, animation obtained by } \\
84 \% \text { through the individual test with a } \\
\text { sample of } 9 \text { students }\end{array}$ \\
\hline 3 & $\begin{array}{l}\text { Field } \\
\text { Study }\end{array}$ & $\begin{array}{l}75 \% \text { were obtained from the sum } \\
\text { of each criterion score (see table } 4 \text { ) }\end{array}$ & $\begin{array}{l}\text { Meet the multimedia elements include: } \\
\text { sound, image, text, animation obtained by } \\
75 \% \text { through the individual test with a } \\
\text { sample of } 15 \text { students }\end{array}$ \\
\hline
\end{tabular}

\begin{tabular}{ll}
\hline Total & $\begin{array}{l}80 \% \text { were obtained from the total } \\
\text { score of the three tests performed } \\
\text { namely individual test, small group } \\
\text { test, and field test }\end{array}$ \\
\hline
\end{tabular}

Description: Multimedia products that had been created were then tested by individual, small group and field study test. They are summarized as in table 1, with an average score of $80 \%$ indicating it meets multimedia elements such as voice, text, image, animation even though the product has not been completely perfect. To get a bigger picture, the following table provides explanation of each value from all three tests performed: 
Table 2. Individual Test Results

\begin{tabular}{cccc}
\hline $\begin{array}{c}\text { Total item } \mathrm{x} \\
\text { sample }\end{array}$ & Category & Significance & $\begin{array}{c}\text { Percentage } \\
\text { Empirical Score }\end{array}$ \\
\hline 42 & Very good & 5 & $41 \%$ \\
\hline 42 & Feasible & 4 & $33 \%$ \\
\hline 14 & Less feasible & 3 & $8 \%$ \\
\hline 0 & Not feasible & 2 & 0 \\
\hline 0 & Awfully feasible & 1 & 0 \\
\hline Total samples & $82 \%$ \\
\hline
\end{tabular}

First; Multimedia products that have been made then tested by individual test to 6 students from each class of 2 people. In this test, 17 multimedia indicators obtained an ideal score of 510 (17 items x 6 samples x 5 maximum scores) found as in table 2 .

Table 3. Small Group Test Result

\begin{tabular}{cccc}
\hline $\begin{array}{c}\text { Total item } \mathrm{x} \\
\text { sample }\end{array}$ & Category & Significance & $\begin{array}{c}\text { Percentage } \\
\text { Empirical Score }\end{array}$ \\
\hline 55 & Very good & 5 & $35 \%$ \\
\hline 60 & Feasible & 4 & $31 \%$ \\
\hline 45 & Less feasible & 3 & $17 \%$ \\
\hline 0 & Not feasible & 2 & 0 \\
\hline 0 & Awfully feasible & 1 & 0 \\
\hline & Total samples & & $84 \%$ \\
\hline
\end{tabular}

Second; small group test was conducted to 9 students from each class of 3 people. In this test, 17 items of validated multimedia indicator obtained an ideal score of 765 (17 items x 9 sample x 5 maximum score), found as in table 3 .

Table 4. Field Study Result

\begin{tabular}{cccc}
\hline $\begin{array}{c}\text { Total item } \mathrm{x} \\
\text { sample }\end{array}$ & Category & Significance & $\begin{array}{c}\text { Percentage } \\
\text { Empirical Score }\end{array}$ \\
\hline 88 & Very good & 5 & $34 \%$ \\
\hline 85 & Feasible & 4 & $26 \%$ \\
\hline 60 & Less feasible & 3 & $14 \%$ \\
\hline 0 & Not feasible & 2 & 0 \\
\hline 0 & Awfully feasible & 1 & 0 \\
\hline & Total samples & & $75 \%$ \\
\hline
\end{tabular}

Third; field study test was conducted to 15 students from each class 5 people. In this test 17 items of validated multimedia indicator obtained ideal score 1275 (17 items x 9 sample x 5 maximum score), found as in table 4.

The results of the multimedia presentation project show good result. It can be concluded that $80 \%$ of students understood better the material presented by combining multimedia elements compared to the presentation of material without multimedia elements. The multimedia product which combined multimedia elements can improve students' creativity and their learning motivation.

Based on the data gathered, the results of test are divided into three groups, namely: individual tests yielded a score percentage of $82 \%$, the small group test produced a score percentage of $84 \%$ and the field test achieved a score of $75 \%$. From the three tests carried out, the product obtained a value of $80 \%$ meaning that multimedia products made with PBL cuold be accepted by students as a form of learning innovation. This innovation refers to the 
integration of technology into the presentation of material by adding elements of text, sound, images, animation and video. This multimedia product made learning more interesting and fostered students' interest in learning. This project also stimulated their creativity in learning. Making multimedia presentations not only improved their ability in terms of knowledge, attitudes, and skills of studentsbut also provided good learning outcomes as well.

There are several learning models which emphasize student-oriented and increase students' interest and creativity. One of them is project-based learning. PBL explores the creativity and innovation created by students so that they can solve real problems. PBL can be interpreted as an activity of choosing, designing, practicing their knowledge. It can also be a comprehensive learning approach to achieve sustainability, improve student collaboration, and nurture their discovery. The project can seize many things to support learning and utilizes life experiences as learning material (Daryanto, 2009).

In this study, students had gone through several stages in creating the multimedia product. They were invited to think about solving problems by making initial planning, the process of making projects, and the stage of evaluating the project. In other words, students had accomplished several steps of PBL. The stages in PBL include: 1) project planning, 2) implementation of production projects, and 3) project evaluation (Herminarto, 2006 in Widowarti, 2015). In this study project planning refers to guiding students in project planning which included: determining real problems, finding alternatives and formulating problem solving strategies. Second, the implementation of the project, in this case, students were guided to carry out product testing. Third, project evaluation refers to assessment of project learning progress, creative problem solving process, progress of team or individual work, experimentation and reflection, work results and individual or group presentations, project reports, portfolios.

In this study, research and development of teaching material products were developed by developing learning web namely www.elearning-ambarsrilestari.web.id. The product of this teaching material refers to presentations product by combining multimedia elements so that the presentation of the material is more interesting and can be better understood. Teaching materials are stored in each online class, each in the form of papers, modules, and presentations that have been added to other applications to upload on youtube channels so students can follow their respective classes online through the e-learning website that has been provided and can conduct discussions through chat forums in the e-learning class.

Learning outcomes with multimedia teaching materials show students' mastery of learning from the delivery of materials with multimedia teaching materials. The multimedia material provided more new experiences for students and add creativity and innovation for students. This is in line with the result of interview with the students. They preferred the multimedia material for learning compared to conventional method. The intended learning outcomes in this study refers to students' improvement in understanding the material delivered.

The test results show the average total value of $80 \%$ of teaching products have met the multimedia elements such as voice, text, images, animation, and has been integrated on the web e-learning on the youtube channel and student performance such as paper and Slideshare is on e-portfolio. The test results of $80 \%$ indicate that students better understood the material by presenting presentations that combined multimedia elements in its delivery.

Based on the survey results, the presence of images, animations, and videos helped students to understand the material presented. The result show that that multimedia presentations was more interesting and the material could be better understood by students. The concepts described in the multimedia project are varied and not monotonous compared to the presentation of material without multimedia elements. As an early reason for the development of project-based learning, as described by (Chang, 2012), in his research that PBL 
can improve analytical skills, improve information-seeking skills, promote the ability of group discussions, develop thinking skills, encourage student skills problem solving, and can help improve students' learning motivation.

Implementation of multimedia-based teaching must be supported by various factors. Those factors will make the multimedia content utilized by all learners. Supporting factors include : promoting creativity and innovation from students, increasing learning motivation and facilitating understanding of the material. Things to consider before implementing this technology in teaching include (Lee \& Owen, 2004):

1. The audience of learning methods

2. Characteristics and personal culture of the target population.

3. Specific characteristics of each of the multimedia components used.

4. The advantages and disadvantages of each component (video, audio, animation, graphics, and others)

5. Specific characteristics that can not be separated from each material presented (different treatment among lectures).

6. The need to accommodate different models (styles) in learning.

7. The importance of interactivity and the active participation of users.

8. The need for a virtual environment (virtual learning environment) such as web-based applications that support.

9. The learning process should be continuous continuity, not sporadic and disconnected events.

The above references have been taken into consideration in this study. This study had determined level of education so the material to be delivered was in accordance with the level of student. This was done to ensure that learning can be more focused and it can get maximum learning outcomes. Sutarno \& Mukhidin (2013) states that multimedia-based learning can motivate students in learning. there are several reasons for this: 1) interesting interactive multimedia is capable of improving learning. Students are seriously listening to learning and do not feel bored, 2) interactive multimedia allows students to easily understand the contents of the material, 3) multimedia interactive with communicative language stimulates students to learn independently, 4) interactive multimedia can improve learning outcomes. A lot of research has been done, as for the difference from this study with previous research is the teaching of projectbased multimedia that depicts the performance of the products produced by the students by choosing, planning, writing and producing multimedia presentations where the product is integrated with e-learning available on web http: //www.elearning-ambarsrilestari.web.id.

This study promotes E- learning. E-learning is a form of learning that uses electronic media ('e') to support the teaching and learning process; which combines all learning activities both individually and in groups directly or not. E-learning is web-based learning that is done online by using an internet network as a link to be able to be done not directly like face-to-face classes but learning can be done anytime and anywhere. E-learning in this study is a learning media that is used as a learning tool on the web that has been made before to upload assignments made by students so that these assignments can be stored online and can be seen or studied anytime, most importantly connected to the internet. E-learning will combine all educational activities carried out by individuals or groups that work online or offline, and synchronously or asynchronously through the network or independent computers and other electronic devices (Naidu, 2006).

In addition to E-learning, this study promotes Web-based learning. Web-based learning is also the same as conventional learning but not face-to-face. The idea of web-based learning is to provide online learning methods and provide different learning experiences to students so that they can know and use online learning separately outside the classroom which is designed 
like in class but is online (not face to face). The main idea of web-based learning is because online learning has been done a lot in the teaching process so that it can add insight and other learning experiences and motivate students to use online learning in addition to conventional learning with face to face. While classes are also made and learning resources are uploaded into their respective classes in the form of teaching materials/materials. Assignments up to online examinations and the results of assessment are already exists in the system. Chat in online classes provides space for students to discuss. In this study, the web learning is made and can be accessed in the http://elearning-ambarsrilestari.com. This platform provided learning experiences to students, namely online learning connected to the internet.

In this study, PBL had been implemented. PBL is one of the learning methods where in this learning, project-based learning provides different experiences for students to be able to use online learning model. It uses problems as a first step in collecting, identifying and integrating new knowledge based on their experience in the problem-solving process. As Adinugraha's (2018) research which implemented PBL. This is in accordance with the objectives of the lecture which is to produce students who are able to create learning media to support learning activities. In line with Assidik (2018) in his research, the findings showed an increase in student activeness in preparing learning media products, students were also required to present the use of learning media products created so as to further develop the skills of capable and superior students. Another study conducted by Anita (2017) explains that implementing PBL fosters students' mathematical creative thinking skills.

The implementation of PBL aims to create effective learning activities. In PBL it is hoped that the learning process will be more effective by absorbing the abilities of students in aspects of knowledge, attitudes, and skills. PBL models fall into the classification of effective learning, as stated by Setyosari (2014) where effective learning includes several things, namely: 1) learning quality, 2) adequate learning levels, 3) rewards, and 4) time. In addition, factors that must be considered in designing learning, namely: learning objectives, teachers, methods, teaching materials, media and environmental factors ((Resmini, Djuanda, \& Cahyani, 2009). Guilford's opinion (in Munandar, 2009) suggests that creative thinking is the ability to see various possible solutions to a problem that must be seen as a "process" and involves the stages of the creative thinking process.

The creativity that grows can make learning more active because creativity will give birth to various innovations. Creativity in PBL is where students are stimulated to issue ideas related to teaching innovation by combining multimedia elements in the process of making material presentations. The objectives of implementing PBLinclude: a) linking the real world with learning, b) making students work in a directed manner, c) making students work together / collaboratively, d) encouraging students to conduct investigations, and e) solving problems. Project-based learning links many students' thinking skills so that they are multi-intelligence in carrying out projects carried out in the surrounding environment.

PBL has been done by experts. It has been carried out in previous studies such as explained by Adinugraha (2018) states that project-based learning inspires student knowledge in choosing and making appropriate learning media. PBL triggers discussion of team teaching (Baeten \& Simons, 2014; Chang \& Lee, 2010; Tamim \& Grant, 2013); collaborative teaching (Chu \& Chow, 2011), digital storytelling (Hung, Hwang, \& Huang, 2012), project-based learning in learning history (Hernández-Ramos \& De La Paz, 2009), electricity (Martínez, Herrero, \& De Pablo, 2011), physic (Siswanto, 2011) interdisciplinary (Stozhko, Bortnik, Mironova, Tchernysheva, \& Podshivalova, 2015).

E learning has something to do with internet. Online delivery uses the network to convey information from one server in the internet network. Online learning is a tool in webbased learning that uses internet networks to be able to connect one server to another server so 
that online learning can be done that is like web-based learning. Offline shipments were stored with removable storage tools. The storage device must be capable of storing large data according to the characteristics of multimedia data, such as DVD or CD-ROM. The relationship with this research is to save assignment files made by students to be uploaded into online learning so that they can be used in teaching flexibly whenever and wherever important is connected to the internet

Multimedia has the capacity to integrate learning resources (Azlina, Masood, \& Apandi, 2014). Multimedia applications should have the potential to link learning activities by combining media. The relationship between multimedia learning and this research is the form of assignments made by students in the form of material presented in a presentation. It combined multimedia elements so that it could be more interesting and easier to understand the content of the material presented. Multimedia in learning can provide answers to forms of learning that use a traditional approach that tends to make teachers less interactive. Newby (2000) explained that to know the quality of multimedia, several things must be considered namely: 1) methods, namely techniques and procedures used in learning (such as: cooperation, games, discussion); 2) media used in learning to attract students (multimedia, video, text, photos and animations); 3) materials, ie learning content, including: orientation, motivation, application and evaluation. Innovative learning can be made through contextual models with project-based learning (Cord, 2001).

PBL focuses on key concepts and principles of knowledge and engages students in problem-solving activities and other meaningful tasks, providing and providing students opportunities to be creative and self-reliant in producing works based on reality (Okudan \& Rzasa, 2006). The findings of this study are that $80 \%$ of students are more motivated in understanding the material by presenting presentations that combine multimedia elements to increase learning motivation. In PBL students learn on real issues, which can produce permanent knowledge and organize their own learning projects (Thomas, 2000). PBL is an effective educational approach that focuses on creative thinking, problem-solving, and interaction between students and their peers to create and use new knowledge. This is primarily done in the context of active and communicative learning (Asan \& Haliloglu, 2005). PBL is constructive learning that emphasizes students to build their own knowledge. A project-based approach can be seen as one approach to creating an environment that encourages students to build their own knowledge and learning skills. Holm (2011) states, PBL is described as "studentcentered learning" that occurs over a period of time, where students choose, investigate, create products, deliver performance results for authentic assessment.

The contribution of this research to Islamic education is to develop teaching materials that the teaching in this research is the delivery of material presented through presentations by combining multimedia elements. This combination can create creativity and increase learning motivation and provide learning independence to students. The teaching can provide novelty in combining multimedia elements such as sound, images, animation and even an explanation of teaching material through the addition of software in the form of applications for video creation. By making multimedia presentations it is expected that PAI teachers can present more innovative material so that the learning process can be more effective and students more actively listen to the material presented.

\section{CONCLUSION}

PBL using multimedia provides benefits for students in delivering learning materials by integrating sound, text, image, video and animation elements with additional Camtasia applications so that multimedia products are produced better than without additional presentation-making applications. Thus, students become creative and innovative in the delivery 
of teaching material. Multimedia learning products in the form of video presentations can be found on youtube and all integrated on e-learning website entitled www.elearningambarsrilestari.web.id. Multimedia products were stored on youtube. Other than that, such as paper, was uploaded on each student's blog. Some of the written papers were re-arranged in module form then being uploaded on each student's Slideshare. Furthermore, all student performance results were stored in e-portfolio on www.ambarsrilestari. web.id.

\section{BIBLIOGRAPHY}

Adinugraha, F. (2018). Model Pembelajaran Berbasis Proyek Pada Matakuliah Media Pembelajaran. Jurnal SAP, 3(1), 2527-2967. https://doi.org/10.30998/sap.v3i1.2728

Anita, I. W. (2017). Implementasi Pembelajaran Berbasis Proyek Untuk Menumbuhkan Kemampuan Berpikir Kreatif Mahasiswa. Jurnal Penelitian Pembelajaran Matematika, 10(1), 125-131. http://dx.doi.org/10.30870/jppm.v10i1.1287

Asan, A., \& Haliloglu, Z. (2005). Implementing Project-Based Learning in Computer Classroom. The Turkish Online Journal of Educational Technology, 4(3). Retrieved from http://www.tojet.net/articles/ 4310.doc.

Assidik, G. K. (2018). Implementasi Pembelajaran Berbasis Proyek (Project Based Learning) Pada Matakuliah Media Pembelajaran di Prodi Pendidikan Bahasa Indonesia Universitas Negeri Surakarta. Transformatika: Jurnal Bahasa, Sastra, dan Pengajarannya, 2(2), 116-129. https://doi.org/10.31002/transformatika.v2i2.829

Azlina, N., Masood, M., \& Apandi, N. E. F. Z. (2014). Development of Multimedia Application for Learning Algebra. Journal of Education and Practice, 5(5), 156-159.

Baedowi, S., \& Aksin, N. (2017). Penerapan Pembelajaran Berbasis Proyek (Project Base learning) Untuk Meningkatkan Pemahaman Konsep Mahasiswa Pada Perkuliahan PAI di Prodi PGSD Universitas PGRI Semarang. Prosiding Seminar Hasil Penelitian. Universitas PGRI Semarang, 1-6. Retrieved from prosiding.upgris.ac.id/index.php/LPPM2017/ LPPM2017/paper/view/1975

Baeten, M., \& Simons, M. (2014). Student Teachers' Team Teaching: Models, Effects, and Conditions for Implementation. Teaching and Teacher Education, 41, 92-110. https://doi.org/10.1016/j.tate.2014.03.010

Chang, L. C., \& Lee, G. C. (2010). A Team-Teaching Model for Practicing Project-Based Learning in High School: Collaboration Between Computer and Subject Teachers. Computers \& Education, 55(3), 961-969. https://doi.org/10.1016/j.compedu.2010.04.007

Chang, S. C. (2012). Integration of Project Based Learning Strategy with Mobile Learning: A Case study of mangrove wetland Ecology exploration project. Tamkang Journal of Science and Engineering, 14(3), 265-273.

Chapman, P., \& Chapman, J. (2004). Digital Multimedia (2nd ed). London: John Wiley \& Sons, Ltd.

Chu, S. K. W., \& Chow, K. (2011). Using Collaborative Teaching and Inquiry Project-Based Learning to Help Primary School Students Develop Information Literacy and Information Skills. Library \& Information Science Research, 33(2), 132-143. https://doi.org/10.1016/j.lisr.2010.07.017

Cord. (2001). Contextual Learning Resource. Retrieved from http://www.cord.org.

Daryanto. (2009). Demonstrasi Sebagai Metode Belajar. Jakarta: Depdikbud.

Dick, W., Carey, L., \& Carey, J. O. (2009). The Systematic Design of Instruction (7th editions). NewJersey: Pearson.

Fannani, T. (2018). Pengembangan Media Pembelajaran Multimedia Berbasis Project Based Learning Pada Pelajaran Pendidikan Kemuhammadiyahan Siswa Kelas X SMA 
Muhammadiyah 1 Gresik. Jurnal TAMADDUN- FAI UMG, XIX(2), 157-166. http://dx.doi.org/10.30587/tamaddun.v0i0.705

Fatmawati, B. (2011). Pembelajaran Berbasis Proyek Untuk Meningkatkan Ketrampilan Berpikir Kreatif Mahasiswa. Journal Pengajaran MIPA, 16(2), 85-92. http://dx.doi.org/10.18269/jpmipa.v16i2.224

Herminarto. (2006). Implementasi Pembelajaran Berbasis Proyek Pada Bidang Kejuruan. Cakrawala Pendidikan. Jurnal Ilmiah Pendidikan, XXV (2), 291-308. https://doi.org/10.21831/cp.v1i2.8515

Hernández-Ramos, P., \& De La Paz, S. (2009). Learning History in Middle School by Designing Multimedia in a Project-Based Learning Experience. Journal of Research on Technology in Education, 4(2), 151-173.

Holm, M. (2011). Project-Based Instruction: A Review of the Literature on Effectiveness in Pre-Kindergarten Through 12th-grade classrooms. InSight: Rivier Academic Journal, 7(2), 113.

Hung, C. M., Hwang, G. J., \& Huang, I. (2012). A Project-Based Digital Storytelling Approach for Improving Students' Learning Motivation, Problem-Solving Competence, and Learning Achievement. Journal of Educational Technology \& Society, 15(4), 368.

Idkhan, A. M. (2017). Analisis Model Pembelajaran Berbasis Proyek Pada Matakuliah Kewirausahaan di Perguruan Tinggi. Seminar Nasional. Dipresentasikan pada Lembaga Penelitian UNM. Retrieved from http://ojs.unm.ac.id/semnaslemlit/article/view/4279

Jalaluddin. (2016). Model-model Pembelajaran dan Implementasi Dalam RPP. Palembang: Media Mutiara Lentera.

Kurdish, F. N. (2009). Penerapan Student Centered Learning dari Teacher Centered Learning. Jurnal Forum Kependidikan, 28(2), 108-113.

Lee, W. W., \& Owen, D. L. (2004). Computer-Based Training, Web-Based Training, and Distance Learning. Turkish Online Journal of Distance Education-TOJDE, 5(3). Retrieved from http://tojde.anadolu.edu.tr/volume-5-issue-2-year-2004.html

Mahnun, N. (2012). Media Pembelajaran: Pemilihan dan Implementasinya Dalam Pembelajaran. An-Nida Jurnal Pemikiran Islam, 37(1), 27-34.

Makky, M., \& Chatib, O. C. (2016). Pengembangan Metode Pembelajaran Project Based Learning Berbasis Internet dan Media Social. Seminar Nasional Pengembangan Pendidikan Tinggi, 105-111. Padang.

Martínez, F., Herrero, L. C., \& De Pablo, S. (2011). Project-Based Learning and Rubrics in The Teaching of Power Supplies and Photovoltaic Electricity. IEEE Transactions on Education, 54(1), 87-96.

Munandar, S. C. U. (2009). Kreativitas dan Keberbakatan: Strategi Memujudkan Potensi kreatif dan Bakat. Jakarta: Gramedia Pustaka.

Naidu, S. (2006). A Guidebook of Principles, Procedures, and Practises,. New Delhi: : Commonwealth Educational Media Center for Asia (CEMCA).

Naimah, N. J. (2015). Penerapan Pembelajaran Berbasis Proyek Berbantuan E-Learning untuk Meningkatkan Hasil Belajar Siswa. Jurnal Inovasi Pendidikan Kimia, 9(2), 1566-1574.

Newby, T. J. et. al. (2000). Instructional Technology for Teaching and Learning. New Jersey, USA: Merrill an Imprint of Prentice-Hall.

Okudan, G. E., \& Rzasa, S. E. (2006). A Project-Based Approach to Entrepreneurial Leadership Education. Journal Technovation, 26(2), 195-210. https:// doi.org/10.1016/j. technovation. 2004.10.012

Patmanthara, S. (2016). Implementasi Model Pembelajaran Berbasis Proyek Untuk Meningkatkan Aktivitas dan Hasil Belajar Mahasiswa. Journal TEKNO, 26(6), 100-106. 
Philip, M. K., Jackson, T. K., \& Wando, D. (2011). The effect of computer-assisted instruction on student's attitudes and achievement in matrices and transformations in secondary schools in UasinGishu district, Kenya. International Journal of Curriculum and Instruction, 1(1), 53-62.

Rais, M. (2010). Project-based learning: Learning innovation that is oriented towards soft skills. National Seminar on Technology and Vocational Education in the Faculty of Engineering, 1-17. Surabaya State University.

Republic of Indonesia Minister of Education and Culture Regulation Number 65 of 2013 concerning Basic and Secondary Education Process Standards.

Resmini, N., Djuanda, D., \& Cahyani, I. (2009). Pembinaan dan Pengembangan Pembelajaran Babasa dan Sastra Indonesia. Bandung: UPI Press.

Sanjaya, W. (2006). Learning Strategies are Oriented to Standard Educational Processes. Jakarta: Kencana.

Setyosari, P. (2014). Menciptakan Pembelajaran Yang Efektif dan Berkualitas. Journal Inovasi dan Teknologi Pembelajaran, 1(1), 20-30.

Siswanto, J. (2011). Compact Disk Online (Cd-O) sebagai Multimedia Interaktif Pembelajaran Fisika Berbasis Proyek. Jurnal Penelitian Pembelajaran Fisika, 2(1), 1-92.

Stozhko, N., Bortnik, B., Mironova, L., Tchernysheva, A., \& Podshivalova, E. (2015). Interdisciplinary project-based learning: Technology for improving student cognition. Research in Learning Technology, 23(1), 1-13. https://doi.org/10.3402/rlt.v23.27577

Sutarno, E., \& Mukhidin. (2013). Pengembangan Model Pembelajaran Berbasis Multimedia Interaktif Pengukuran untuk Meningkatkan Hasil dan Kemandirian Belajar Siswa SMP di Kota Bandung. Jurnal Pendidikan Teknologi dan Kejuruan, 21(3), 203-218. https://doi.org/10.21831/jptk.v21i3.3258

Tamim, S. R., \& Grant, M. M. (2013). Definitions and uses: A Case study of teachers implementing projectbased learning. 7(2). https://doi.org/10.7771/1541-5015.1323

Thomas, J. W. (2000). A review of research on project-based learning. Retrieved from http://www.autodesk.com/foundation

Wulandari, F. E. (2016). Pengaruh Pembelajaran Berbasis Proyek Untuk Melatihkan Ketrampilan Proses Mahasiswa. Jurnal PEDAGOGI, 5(2), 247-254. https://doi.org/10.21070/pedagogia.v5i2.257 